\title{
Catalytic Oxidation of Aniline by Aqueous Hydrogen Peroxide in the Presence of Some Heteropolyoxometalates
}

\author{
Mohammad. H. Alizadeh ${ }^{a}$ and Reza Tayebee ${ }^{*, b}$ \\ ${ }^{a}$ Department of Chemistry, Ferdowsi University, Mashhad, Iran \\ ${ }^{b}$ Department of Chemistry, Sabzevar University, Sabzevar, Iran, 397
}

\begin{abstract}
Anilina foi convertida em nitrosobenzeno e nitrobenzeno por oxidação com peróxido de hidrogênio aquoso $30 \%$. A reação foi catalisada por vários heteropolioxometalatos, à temperatura ambiente, em diclorometano, em condições bifásicas. Descobriu-se que $\mathrm{H}_{3} \mathrm{PW}_{12} \mathrm{O}_{40}$ é o melhor catalisador na oxidação da anilina. $\mathrm{Na}_{3} \mathrm{PW}_{9} \mathrm{Mo}_{3} \mathrm{O}_{40}$ e $\mathrm{K}_{4} \mathrm{SiW}_{9} \mathrm{Mo}_{2} \mathrm{O}_{40}$ também exibiram alta atividade na oxigenação. Agentes de transferência de fase e temperatura também contribuíram para a eficiência da oxidação.
\end{abstract}

Aniline was selectively converted into the corresponding nitrosobenzene and nitrobenzene by oxidation with $30 \%$ aqueous hydrogen peroxide. The reaction was catalyzed by various heteropolyoxometalates, at room temperature, in dichloromethane under two-phase conditions. Findings show that $\mathrm{H}_{3} \mathrm{PW}_{12} \mathrm{O}_{40}$ is the best catalyst in the oxidation of aniline. $\mathrm{Na}_{3} \mathrm{PW}_{9} \mathrm{Mo}_{3} \mathrm{O}_{40}$ and $\mathrm{K}_{4} \mathrm{SiW}_{9} \mathrm{Mo}_{2} \mathrm{O}_{39}$ also displayed high reactivity in the oxygenation system. Phase transfer agents and temperature increase also contribute to the efficiency of the oxidation.

Keywords: oxidation, polyoxometalates, aniline

\section{Introduction}

Oxidation of organic substrates by aqueous hydrogen peroxide is very attractive from the viewpoint of industrial technology and synthetic purposes. ${ }^{1}$ Polyoxometalates have been widely studied as small compact oxide clusters. ${ }^{2-}$ ${ }^{5}$ Their redox properties and high electron density are ideal for their use as catalysts. It is well known that heteropolyoxometalates catalyze homogeneous oxidation of a wide range of organic compounds such as olefins, ${ }^{6,7,8}$ thioethers, ${ }^{6}$ and alcohols ${ }^{7}$ with several terminal oxidants such as alkyl hydroperoxide, ${ }^{9}$ molecular oxygen, ${ }^{10}$ iodosyl benzene, ${ }^{8}$ as well as hydrogen peroxide. ${ }^{11}$

Oxidation of amines to their corresponding oxygencontaining derivatives has attracted much attention during the past few decades. ${ }^{12}$ Azobenzene, ${ }^{13,14}$ azoxybenzene, ${ }^{15,16}$ nitrobenzene ${ }^{17,18}$ and nitrosobenzene, ${ }^{19-21}$ have been formed in the oxidation of aniline by organic ${ }^{22}$ and inorganic ${ }^{23}$ oxidants. The product composition in the oxygenation of amines depends on the oxidant, catalyst, quaternary ammonium salts, and reaction conditions employed. ${ }^{16}$

* e-mail: Rtayebee@sttu.ac.ir
Tungsten- and molybdenum-based heteropolyoxometalates have received attention as promising oxidation catalysts in the selective oxygenation of aromatic and aliphatic amines. ${ }^{24,25}$ Recently, Ishii and colleagues have reported their results on the oxidation of amines by aqueous hydrogen peroxide under the influence of synthetic PCWP, peroxotungstophosphate, and CWP, tris(cetylpyridinium)12-tungstophosphate. ${ }^{26}$ In this system, $\mathrm{H}_{3} \mathrm{PW}_{12} \mathrm{O}_{40}$ revealed little activity in $\mathrm{CHCl}_{3}$ and its efficacy varied with the reaction conditions.

We hereby present our results in the selective and fast oxidation of aniline by hydrogen peroxide in the presence of several simple heteropolyoxometalates at room temperature under simple reaction conditions.

\section{Results and Discussion}

Table 1 introduces the results of aniline oxidation into nitrosobenzene as the major product and nitrobenzene as the minor product. The oxidant is $30 \% \mathrm{H}_{2} \mathrm{O}_{2}$ in the presence of some heteropolyoxometalates as catalysts under a two-phase reaction condition. Aniline is converted to nitrosobenze by 2 equivalents of $30 \% \mathrm{H}_{2} \mathrm{O}_{2}$ with $>86 \%$ selectivity at room temperature in dichloromethane. The reaction time is less than 
Table 1. Oxidation of Aniline with $30 \% \mathrm{H}_{2} \mathrm{O}_{2}$ Catalyzed by Heteropolyoxometalates ${ }^{\mathrm{a}}$

\begin{tabular}{|c|c|c|c|c|c|}
\hline Catalyst & Conv. $(\%)^{\mathrm{b}}$ & Nitroso-Yield $(\%)$ & Nitro-Yield(\%) & Selec. $(\%)$ & Time(min) \\
\hline Without & 0 & 0 & 0 & 0 & 240 \\
\hline $\mathrm{H}_{3} \mathrm{PW}_{12} \mathrm{O}_{40}$ & $55.5(92)$ & $49.5(82.5)$ & $6.2(9.8)$ & $89(89.7)$ & $15(50)$ \\
\hline $\mathrm{H}_{3} \mathrm{PW}_{12} \mathrm{O}_{40}{ }^{\mathrm{c}}$ & $91(90.2)$ & $82.5(81.2)$ & $8.4(9)$ & $90.6(90)$ & $15(30)$ \\
\hline $\mathrm{K}_{5} \mathrm{Na}_{2} \mathrm{PW}_{11} \mathrm{O}_{39}$ & $43.5(86)$ & $38.2(76.2)$ & $5.3(9.8)$ & $87.8(88.6)$ & $20(60)$ \\
\hline$(\mathrm{TBA})_{7} \mathrm{PW}_{11} \mathrm{O}_{39}$ & $20(54)$ & $17(46.5)$ & $3(7)$ & $85(86.1)$ & $35(150)$ \\
\hline$(\mathrm{TBA})_{8} \mathrm{SiW}_{11} \mathrm{O}_{39}$ & $34(59.7)$ & $28.8(52)$ & $5.4(7.9)$ & $84.7(87.1)$ & $35(150)$ \\
\hline $\mathrm{K}_{5} \mathrm{PW}_{11} \mathrm{ZnO}_{39}$ & $2(5)$ & $2(5)$ & $0(0)$ & $100(100)$ & $40(180)$ \\
\hline $\mathrm{K}_{6} \mathrm{P}_{2} \mathrm{~W}_{18}^{11} \mathrm{O}_{62}{ }^{39}$ & $3.5(9.4)$ & $3.5(8.7)$ & $0(0.7)$ & $100(92.5)$ & $30(60)$ \\
\hline $\mathrm{H}_{14} \mathrm{P}_{5} \mathrm{~W}_{30} \mathrm{O}_{110}$ & 20 & 20 & 0 & 100 & 150 \\
\hline $\mathrm{Na}_{3} \mathrm{PW}_{9} \mathrm{Mo}_{3} \mathrm{O}_{40}$ & $20(60)$ & $18.4(56)$ & $1.6(3.3)$ & $92(93.3)$ & $35(180)$ \\
\hline $\mathrm{K}_{4} \mathrm{SiW}_{9} \mathrm{Mo}_{2} \mathrm{O}_{39}$ & $41.5(82.7)$ & $38.5(76.6)$ & $3(6.1)$ & $2.7(92.6)$ & $35(130)$ \\
\hline $\mathrm{H}_{3} \mathrm{PMo}_{12} \mathrm{O}_{40}$ & $8.5(50)$ & $8.5(48.5)$ & $0(1.2)$ & $100(97)$ & $15(165)$ \\
\hline$(\mathrm{TBA})_{3} \mathrm{PMo}_{12} \mathrm{O}_{40}$ & $3.5(21)$ & $3.5(20.5)$ & $0(0.5)$ & $100(97.6)$ & $15(180)$ \\
\hline $\mathrm{Na}_{6} \mathrm{P}_{2} \mathrm{Mo}_{18} \mathrm{O}_{62}$ & $3.4(8.1)$ & $3.4(8)$ & $0(.01)$ & $100(98.7)$ & $60(150)$ \\
\hline$(\mathrm{TBA})_{3}\left\{\mathrm{PO}_{4}\left[\mathrm{WO}\left(\mathrm{O}_{2}\right)_{2}\right]_{4}\right\}$ & $17(40)$ & $15.2(36)$ & $2(3.8)$ & 89.4(90) & $40(120)$ \\
\hline$(\mathrm{TBA})_{3}\left\{\mathrm{PO}_{4}\left[\mathrm{MoO}\left(\mathrm{O}_{2}\right)_{2}\right]_{4}\right\}$ & $5(16.5)$ & $5(15.8)$ & $0(0.6)$ & $100(95.7)$ & $60(180)$ \\
\hline
\end{tabular}

${ }^{a}$ Aniline $(4 \mathrm{mmol})$ was allowed to react with $30 \% \mathrm{H}_{2} \mathrm{O}_{2}(8 \mathrm{mmol})$ in the presence of catalyst $(0.015 \mathrm{mmol}), \mathrm{n}$ equivalents of $\mathrm{CPC}(\mathrm{n}=$ charge on polyanion $)$ if present, in dichloromethane $(7 \mathrm{ml})$ under air at room temperature for the required time. ${ }^{b}$ Determined by GLC. ${ }^{\mathrm{c}}$ under reflux.

3 hours. Nitrosobenzene monomer is formed as a clear greencolored solution in dichloromethane. It later converts into its dimeric form as yellowish solid. A typical $\mathrm{H}_{3} \mathrm{PW}_{12} \mathrm{O}_{40}$ catalyzed oxidation of aniline to its corresponding products, has a $55.5 \%$ yield with $89 \%$ selectivity after only 15 minutes. $\mathrm{K}_{5} \mathrm{Na}_{2} \mathrm{PW}_{11} \mathrm{O}_{39}$ is about as efficient catalyst as $\mathrm{H}_{3} \mathrm{PW}_{12} \mathrm{O}_{40}$. It leads to $86 \%$ nitrosobenzene with $88.6 \%$ selectivity after $60 \mathrm{~min}$. The catalytic activity of $\mathrm{H}_{3} \mathrm{PMo}_{12} \mathrm{O}_{40}$ is much less than $\mathrm{H}_{3} \mathrm{PW}_{12} \mathrm{O}_{40}$. It leads to $8.5 \%$ and $50 \%$ of product yield after 15 and 165 minutes, respectively, with $97-100 \%$ selectivity. The selectivity of oxidations with molybdenum analogs of heteropolyoxometalates is higher than those of tungstophosphates.

$\mathrm{H}_{3} \mathrm{PW}_{12} \mathrm{O}_{40}$ shows comparable selectivity but higher conversion yield and requires a shorter reaction time at reflux. $\mathrm{H}_{3} \mathrm{PW}_{12} \mathrm{O}_{40}$ resulted in $82.5 \%$ of nitrosobenzene with $90.6 \%$ selectivity after only 15 minutes under reflux. Elevation of reaction temperature has no effect on the selectivity of aniline oxidation with $\mathrm{H}_{3} \mathrm{PW}_{12} \mathrm{O}_{40}$ as catalyst.

To study the effect of presence of phase transfer catalyst(CPC) on the oxidation of aniline, we compared the results obtained with $\mathrm{K}_{5} \mathrm{Na}_{2} \mathrm{PW}_{11} \mathrm{O}_{39}+\mathrm{CPC}$ and (TBA) ${ }_{7} \mathrm{PW}_{11} \mathrm{O}_{39}$. The first system led to $86 \%$ conversion after 60 minutes, while $54 \%$ of conversion was obtained with the latter after $150 \mathrm{~min}$. On the other hand, $\mathrm{H}_{3} \mathrm{PMo}_{12} \mathrm{O}_{40}+\mathrm{CPC}$ and (TBA) ${ }_{3} \mathrm{PMo}_{12} \mathrm{O}_{40}$ systems formed $50 \%$ and $21 \%$ of the products, respectively, at nearly the same times. According to the previous findings, efficiency of CPC and TBA in the formation of the peroxo-complex affects the efficacy of these oxygenations. ${ }^{27}$

The Si-substituted catalysts, $\mathrm{SiW}_{11} \mathrm{O}_{39}{ }^{-8}$ and $\mathrm{K}_{4} \mathrm{SiW}_{9} \mathrm{Mo}_{2} \mathrm{O}_{39}$, showed higher reactivity than $\mathrm{PW}_{11} \mathrm{O}_{39}{ }^{-7}$ and $\mathrm{Na}_{3} \mathrm{PW}_{9} \mathrm{Mo}_{3} \mathrm{O}_{40}$. The first two catalysts led to $34 \%$ and $41.5 \%$ of conversions, respectively, after $35 \mathrm{~min}$., but the latter two resulted in $20 \%$ and $22 \%$ conversions, respectively, at the same time. In contrast, the $\mathrm{Zn}(\mathrm{II})-$ substituted polytungstophosphate, $\mathrm{PZnW}_{11} \mathrm{O}_{39}{ }^{-5}$, had the lowest activity. Other Mo- and W- substituted polyoxometalates showed lower activity.

Venturello crystallographically characterized polyperoxometalate $\left\{\mathrm{PO}_{4}\left[\mathrm{WO}\left(\mathrm{O}_{2}\right)_{2}\right]_{4}\right\}^{3-}$ as the active oxygen transfer agent in the oxygenation of organic compounds by hydrogen peroxide catalyzed by $\mathrm{H}_{3} \mathrm{PW}_{12} \mathrm{O}_{40}{ }^{28}$ Accordingly, Scheme 1 represents the general formulation of the catalytic two-phase system in the oxygenation of aniline.

In summary, we have shown that the oxidation of aniline by $35 \%$ hydrogen peroxide, catalyzed by $\mathrm{H}_{3} \mathrm{PW}_{12} \mathrm{O}_{40}$ family (under two-phase conditions at room temperature or under reflux) provides a simple and general procedure for the preparation of nitrosoaniline, that is difficult to prepare selectively by conventional methods. The results clearly demonstrate that this oxidation system is more efficient than Ishii system in the selective oxidation of aniline with hydrogen peroxide. ${ }^{26}$

\section{Experimental}

All starting materials were commercially available and were used without further purification. GLC analyses were performed with Shimadzu capillary column equipped with a flame ionization detector. The polyoxometalates $\mathrm{H}_{3} \mathrm{PW}_{12} \mathrm{O}_{40},{ }^{29} \quad \mathrm{H}_{3} \mathrm{PMo}_{12} \mathrm{O}_{40},{ }^{29} \quad \mathrm{H}_{4} \mathrm{SiW}_{12} \mathrm{O}_{40},{ }^{30,31}$ $\mathrm{K}_{5} \mathrm{Na}_{2} \mathrm{PW}_{11} \mathrm{O}_{39},{ }^{30,31}$ and $\mathrm{K}_{5} \mathrm{PW}_{11} \mathrm{ZnO}_{39},{ }^{32-35}$ were prepared and characterized according to the literature procedures. 


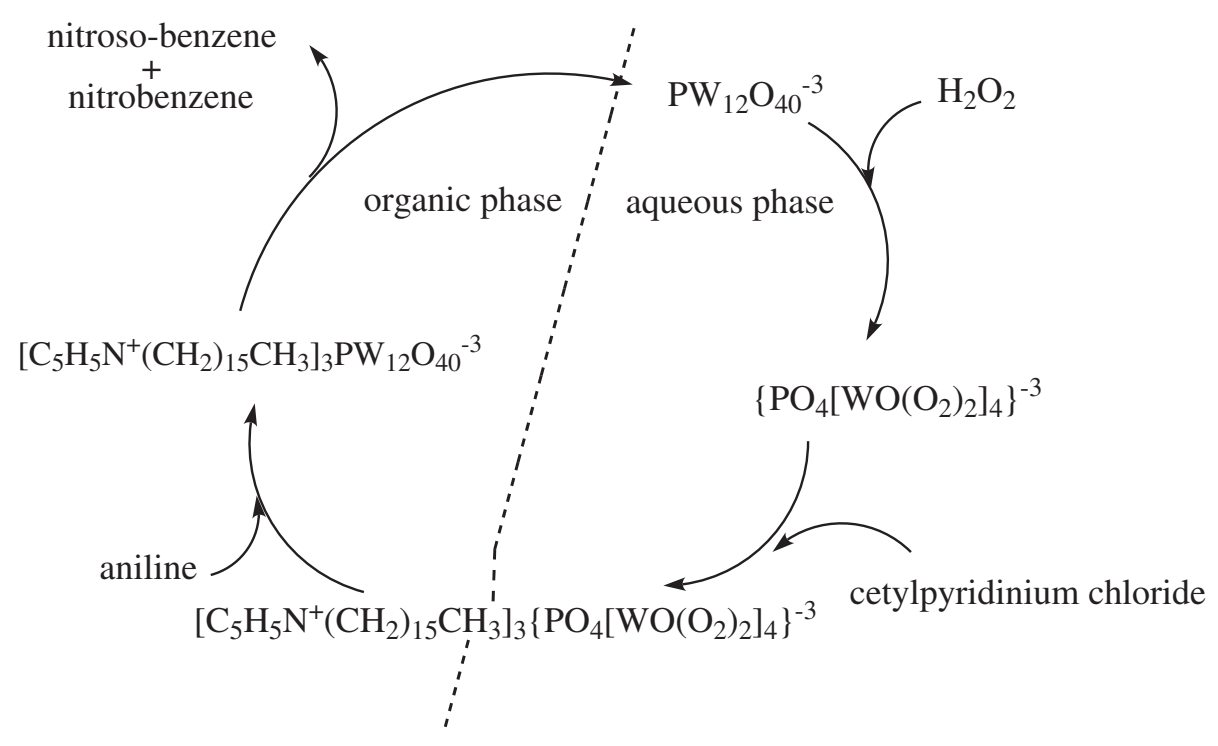

Scheme 1.

General procedure for oxidation of aniline to nitrosobenzene

To a stirred solution of catalyst $(0.015 \mathrm{mmol}), n$ equivalents of $C P C$ ( $\mathrm{n}=$ charge on polyanion) if present, and $30 \% \mathrm{H}_{2} \mathrm{O}_{2}(8 \mathrm{mmol})$ in $\mathrm{CH}_{2} \mathrm{Cl}_{2}(7 \mathrm{~mL})$ was added aniline $(4 \mathrm{mmol})$, and the mixture was stirred at room temperature for the required time. Progress of the reaction was followed by the aliquots withdrawn directly and periodically from the reaction mixture, analyzed by gas chromatography. GLC analyses were performed on a Shimadzu 17A-GC with a flame ionization detector using a $25 \mathrm{~m} \times 0.25 \mathrm{~mm}$ capillary column packed with CPB10 as stationary phase. After decomposition of unreacted hydrogen peroxide, the products were extracted with dichloromethane. The extract was dried over anhydrous sodium sulfate, filtered, and evaporated under reduced pressure. The products were purified by column chromatography on silica gel ( $1 / 5$, ethyl acetate/hexane). The boiling point and spectral data of each product were compared with those of authentic samples and literature values. ${ }^{36}$

\section{Acknowledgement}

The authors gratefully acknowledge the fruitful suggestions of Dr. H. Razavi.

\section{References}

1. Hains, A.H.; Methods for the Oxidation of Organic Compounds, Academic: London, 1985.
2. Pope M. T.; Müller A.; Polyoxometalates: from Platonic Solids to Anti-Retroviral Activity; Kluwer Academic Publishers: Dordrecht, 1994.

3. Alizadeh, M. H.; Harmalker, S. P.; Jeanin, Y.; Pope, M. T.; J. Am. Chem. Soc. 1985, 107, 2662.

4. Alizadeh, M. H.; Razavi, H.; Mohamadi Zonoz, F.; Polyhedron 2003, 22, 993.

5. Alizadeh, M. H.; Eshtiagh Hosseini, H.; Khoshnavazi, R.; J. Mol. Str. 2004, 688, 33.

6. Ballistreri, F. P.; Gaetano, A. B.; Toscano, R. M.; J. Org. Chem. 1992, 57, 7074.

7. Ishii, Y.; Yamawaki, K.; Ura, T.; Yamada, H.; Yoshida, T.; Ogawa, M.; J. Org. Chem.1988, 53, 3587.

8. Hill, C. L.; Brown, R. B.; J. Am. Chem. Soc. 1986, 108, 536.

9. Newmann, R.; Abu-Gnim, C. J.; J. Am. Chem. Soc. 1990, 112, 6025 .

10. Alizadeh, M. H.; Razavi, H.; Bamoharram, F. F.; J. Mol. Catal. A:Chemical 2003, 200, 105.

11. Ishii, Y.; Ogava, M.; Hydrogen Peroxide Oxidation Catalyzed by Heteropoly Acids Combined with Cetylpyridinium Chloride, MY: Tokyo, 1990, vol.3, p. 121-145.

12. Ahluwalia, V.K.; Orgainc Reaction Mechanisms, Parashar Publisher CRC Press: New Delhi, 2002.

13. Wheeler, O. D.; Gonzales, D.; Tetrahedron 1964, 20, 189.

14. Ogata, Y.; Shimizu, H.; Bull. Chem. Soc. Jpn. 1979, 52, 635.

15. Burckard, P.; Fleury, J. P.; Weiss, F.; Bull. Soc. Chim. Fr. 1965, 2730.

16. Barak, G.; Sasson, Y.; J. Org. Chem. 1989, 54, 3484.

17. Emmons, W. D.; J. Am. Chem. Soc. 1957, 79, 5528.

18. White, R.W.; Emmons, W. D.; Tetrahedron 1962, 17, 31.

19. Baumgarten, H. E.; Staklis, A.; Miller, E. M.; J. Org. Chem. 1965, 30, 1203. 
20. Holmes, R. R.; Bayer, R. R.; J. Am. Chem. Soc. 1960, 82, 3454.

21. Mallory, F. B.; Schueller, K. E.; Wood, C. S.; J. Org. Chem. 1961, 26, 3312.

22. Emmons, W.D.; J. Am. Chem. Soc. 1957, 79, 5528.

23. Wheeler, O.D.; Gonzales, D.; Tetrahedron 1964, 20, 189.

24. Sakaue, S.; Sakata, Y.; Nishiyama, Y.; Ishii, Y.; Chem. Lett. 1992, 289.

25. Sloboda-Rozner, D.; Witte, P.; Alsters, P. L.; Newmann, R.; Adv. Synth. Catal. 2004, 346, 339.

26. Sakaue, S.; Tsubakino, T.; Nishiyama, Y.; Ishii, Y.; J. Org. Chem. 1993, 58, 3633.

27. Yadav, G. D.; Pujari, A. A.; Org. Proc. Res. Develp. 2000, 4, 88.

28. Venturello, C.; D’Aloiso, R.; Bart, J. C.; Ricci, M.; J. Mol. Catal. 1985, 32, 107.

29. Wu, H.; J. Biol. Chem. 1920, 43, 189.

30. North, E. O.; Inorg. Synth. 1939, 1, 129.
31. Brevard, C.; Schimpf, R.; Tourne, G.; Tourne, C. M.; J. Am. Chem. Soc. 1983, 105, 7059. General references for preparation of transition metal-substituted derivatives of polyoxometalates $\mathrm{K}_{(10-\mathrm{n})}\left[\mathrm{X}^{\mathrm{n}+} \mathrm{TM}^{\mathrm{II}} \mathrm{W}_{11} \mathrm{O}_{39}\right]\left(\right.$ where $\mathrm{X}^{\mathrm{n}+}=\mathrm{B}(\mathrm{III}), \mathrm{Si}(\mathrm{IV}), \mathrm{P}(\mathrm{V})$, and $\mathrm{TM}=$ d-electron transition metal) are ref. 32-35.

32. Weakley, T. J. R.; Malik, S. A.; J. Inorg. Nucl. Chem. 1967, 29 , 2935.

33. Malik, S. A.; Weakley, T. J. R.; J. Am. Chem. Soc. 1968, 2647.

34. Knoth, W. H.; Domaille, P. J.; Roe, D. C.; Inorg. Chem. 1983, 22, 198.

35. Knoth, W. H.; Domaille, P. J.; Inorg. Chem. 1983, 22, 818.

36. Baumgarten, H. E.; Staklis, A.; Miller, E. M.; J. Org. Chem. 1965, 30, 1203.
Received: April 27, 2004

Published on the web: January 25, 2005 